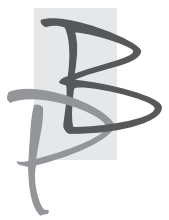

Natalia Szerszeń*

Uniwersytet Warszawski

https://orcid.org/0000-0002-4974-2158

\title{
Konferencja Naukowa „Pamięć Juliusza Słowackiego”. Muzeum Literatury im. Adama Mickiewicza w Warszawie, Warszawa, 22-24 maja 2019 roku. Sprawozdanie
}

Problematyka pamięci i upamiętniania w twórczości Juliusza Słowackiego była głównym, choć niejedynym tematem konferencji naukowej „Pamięć Juliusza Słowackiego", która odbyła się w Muzeum Literatury im. Adama Mickiewicza w Warszawie w dniach 22-24 maja 2019 roku. Uczestnicy poświęcili uwagę sposobom rozumienia przez poetę pamięci, a także badali formy, konteksty i funkcje, w jakich występuje ona w jego twórczości. Różnorodność zaprezentowanych perspektyw badawczych i rozpoznań oraz dyskusje odbywające się podczas każdego z trzech dni trwania konferencji świadczą o żywotności tematu pamięci i upamiętniania $\mathrm{w}$ odniesieniu do literatury romantycznej, a zwłaszcza dzieł i osoby Juliusza Słowackiego. Konferencja była również formą uczczenia przypadającej w tym roku 210. rocznicy urodzin Poety.

Konferencja „Pamięć Juliusza Słowackiego” została zorganizowana dzięki współpracy Uniwersytetu Warszawskiego i Muzeum Literatury im. Adama Mickiewicza w Warszawie. Komitet organizacyjny konferencji tworzyli jej pomysłodawca dr. hab. Olaf Krysowski, prof. UW oraz doktorantka Zakładu Literatury i Kultury Romantyzmu Instytutu Literatury Polskiej UW, mgr Natalia Szerszeń. Ich działania wspierał organizacyjnie dr hab. Jarosław Klejnocki, dyrektor Muzeum Literatury.

Natalia Szerszeń - mgr; doktorantka w Zakładzie Literatury i Kultury Romantyzmu Instytutu Literatury Polskiej na Wydziale Polonistyki Uniwersytetu Warszawskiego. 


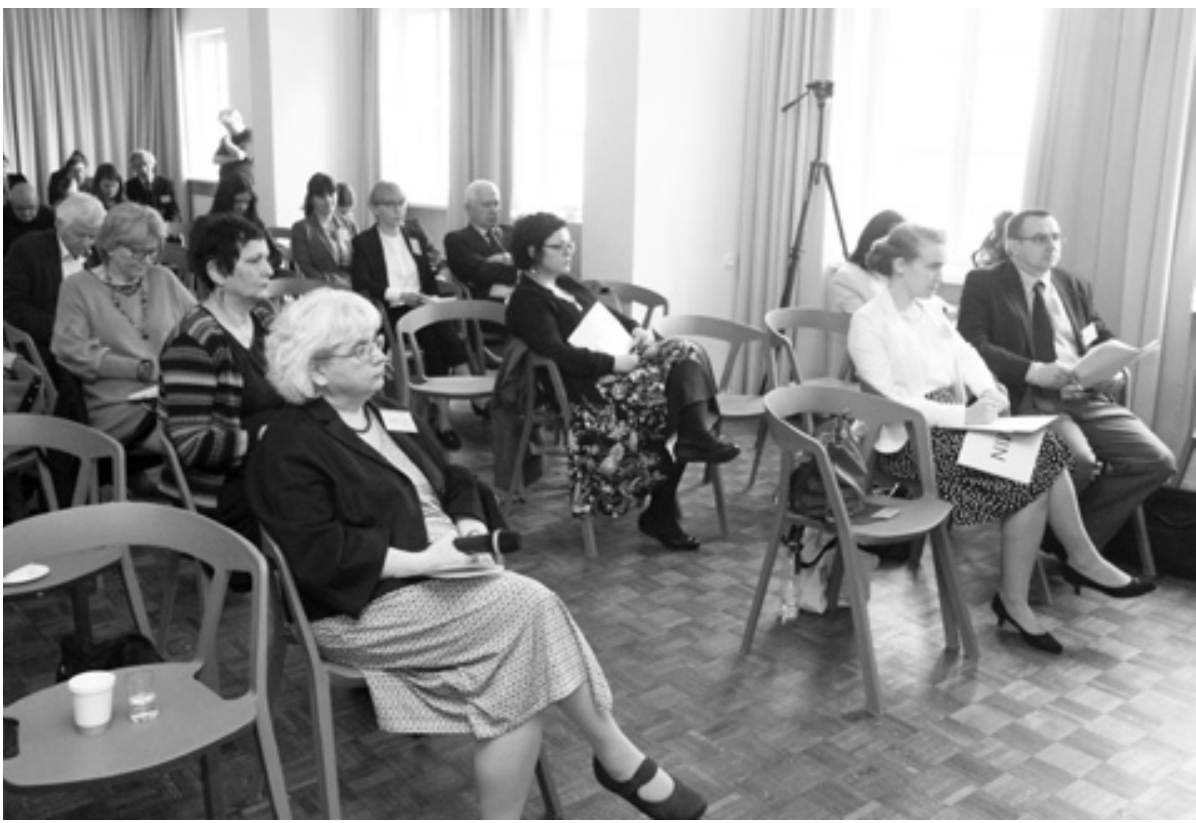

Obrady podczas pierwszego dnia Konferencji. Fot. M. Bociański (Muzeum Literatury)

W programie konferencji zostały uwzględnione między innymi następujące zagadnienia:

- filozofia pamięci (idee, formuły, definicje) w tekstach Słowackiego;

- pamięć w refleksji historycznej i historiozoficznej poety (dyskusje i rozrachunki z przeszłością, ironia w przedstawianiu dziejów, anachronizmy etc.);

• rola pamięci w doświadczeniu teraźniejszości i projektowaniu przyszłości;

• etyczny wymiar pamięci (pamięć wobec dobra i zła, kategoria „sumnienia”);

- autobiografizm i autotematyzm jako formy upamiętniania wizerunku poety;

- figury pamięci (np. mnemotopika - lokalizowanie przez Słowackiego wyobrażeń o przeszłości w określonym miejscu czy krajobrazie - Krzemieniec, Egipt, ruiny, pomniki, groby etc.);

- mitotwórcza funkcja pamięci (mitologizacje, sakralizacje przeszłości), mit jako świadectwo pamięci zbiorowej w utworach Słowackiego;

• pamięć i niepamięć genezyjska/metempsychiczna/mistyczna (zagadnienia anamnezy, hipolepsy, pamięci snu, wizji etc.); 
- genologia pamięci (pamiętnik, raptularz, testament, poemat dygresyjny, wiersz-wspomnienie $\mathrm{i}$ in.) w twórczości pisarza;

- prace plastyczne Słowackiego (rysunki, akwarele) jako nośniki pamięci;

• osoby, zdarzenia i miejsca w pamięci Słowackiego;

- Słowacki w pamięci rodziny, przyjaciół, znajomych.

Obrady w staromiejskiej kamienicy mieszczącej warszawskie Muzeum Literatury zainaugurowali prof. dr hab. Ewa Paczoska, dyrektor Instytutu Literatury Polskiej i organizatorzy konferencji: dr hab. Olaf Krysowski, prof. UW, dr hab. Jarosław Klejnocki i mgr Natalia Szerszeń, dziękując obecnym gościom za zainteresowanie tematem i liczne przybycie, a następnie zapraszając do wysłuchania referatów rozpoczynających obrady. W tej części sesji wystąpili prof. Grażyna Halkiewicz-Sojak (Uniwersytet Mikołaja Kopernika w Toruniu), która zaprezentowała wystąpienie: „Miejsca pamięci” w poezji Juliusza Słowackiego oraz dr hab. Michał Kuziak, prof. UW, „A jeżeli nie będę pamiętać o tym, czym byłem... cóż znaczy to stowo: będę?". Kilka uwag na temat pamięci u Stowackiego przedgenezyjskiego. Prof. Halkiewicz-Sojak podkreśliła istnienie wyraźnego związku między poetycką wyobraźnią Juliusza Słowackiego a jego pamięcią, co omówiła w odniesieniu do obecnych w dziełach poety obrazów Krzemieńca, o którym pamięć, jak dowodziła, autor Złotej Czaszki przez cały okres twórczości aktywnie kreował. Prof. Kuziak skupił się zaś na problematyce pamięci jako źródła tożsamości, wskazując na istnienie u Słowackiego już we wczesnej twórczości opozycji szczęśliwych lat dzieciństwa i nieszczęśliwej, przykrej dla poety chwili obecnej. Przywołał także ważną w dziełach genezyjskich pamięć anamnetyczną, która stała się jego zdaniem podstawą koncepcji antropologicznej późnej twórczości.

Kolejne referaty wygłoszone podczas pierwszego dnia konferencji dotyczyły przede wszystkim pamięci w tzw. przedgenezyjskiej twórczości Słowackiego. Wiele uwagi poświęcono znaczeniu wrażeń zmysłowych - wizualnych, akustycznych, audialnych i olfaktorycznych jako bodźców inicjujących wspominanie oraz wpływających na sposób konstruowania obrazów poetyckich oraz rysunków umieszczanych w raptularzach. W wystąpieniach przywołane zostały także kategoria kryptomnezji i pamięci asocjacyjnej Słowackiego, które odgrywają istotną rolę w poematach dygresyjnych. Powyższe kwestie poruszyli dr hab. Ewa Grzęda, prof. UWr, Juliusza Stowackiego „pamięć florystyczna"; prof. dr hab. Małgorzata Łoboz (Uniwersytet Wrocławski), 
„I dzwoni cicha dusza muzyczna”. Juliusza Stowackiego pamięć w muzyce; dr Urszula Makowska (Instytut Sztuki Polskiej Akademii Nauk), ,, Tyle nowych obrazów tkwi teraz w mojej pamięci...”. O obecności autora w rysunkach Stowackiego z podróży na Wschód oraz dr Olga Taranek-Wolańska (Uniwersytet Wrocławski), ,Chwile referencji”. Asocjacyjna pamięć Juliusza Stowackiego w ,Beniowskim”.

Problem pamięci rozpatrywany był także w kontekstach biograficznym i autobiograficznym oraz w perspektywach metafizycznej i zmysłowej. W ramach tak nakreślonych opozycji uczestnicy konferencji poszukiwali odpowiedzi na pytanie, jak wygląda mapa pamięci (i niepamięci) Słowackiego. Przywołanie kategorii biograficznych sprzyjało też refleksji nad sposobami upamiętnienia poety. Wokół tej problematyki skupiły się kolejne wstąpienia, które wygłosili dr Lidia Romaniszyn-Ziomek (Akademia Techniczno-Humanistyczna w Bielsku-Białej), Wyobraźnia i pamięć w dyskursie autobiograficznym Juliusza Stowackiego; mgr Agnieszka Górska (Uniwersytet Mikołaja Kopernika w Toruniu), Pamięć wczesnych lektur Juliusza Stowackiego; dr Paulina Abriszewska (Uniwersytet Mikołaja Kopernika), , Godzina myśli” - (nie)sensualne wspomnienia oraz mgr Krzysztof Pilichiewicz (Uniwersytet w Białymstoku), „, Ogromna pamięć z myśli uwita tańcucha”. Metempsychoza a autobiografizm w , Godzinie myśli” Juliusza Stowackiego. Ważnym obszarem zainteresowania była także mnemotopika, a zwłaszcza znaczenie Ukrainy i wymiary jej obecności w życiu i dziełach poety. Prelegenci występujący w tej części konferencji wskazywali na przesycenie duchem ukraińskości, a zwłaszcza pamięcią odwiedzanych przez Słowackiego miejsc, twórczości z ostatnich lat życia poety. Wielokrotnie powróciło też pytanie, jaką pamięć o Ukrainie pragnął zachować Słowacki. Badacze wskazywali, że pamięć autora Króla-Ducha była wyjątkowo uwrażliwiona na bodźce i nie miała charakteru sentymentalnego rozpamiętywania. Była pamięcią żywą i służyła kreacji nie tylko oryginalnej formy poetyckiej, lecz także, w zamyśle poety, tożsamości indywidualnej i narodowej. Wokół tych problemów skupione były kolejne wystąpienia, które wygłaszali: dr hab. Marek Troszyński, prof. IBL PAN, „Inaczej na Podolu...”. O ukraińskim imaginarium Stowackiego; doc. dr hab. Maria Bracka (Narodowy Uniwersytet im. Tarasa Szewczenki w Kijowie), Mnemotopos Ukrainy w twórczości Juliusza Stowackiego: kontekst aksjologiczny; dr Teresa Winek (Instytut Badań Literackich PAN), Juliusza 
Stowackiego pamięć Wotynia i Podola (utrwalona w korespondencji); prof. dr hab. Rościsław Radyszewski (Narodowy Uniwersytet im. Tarasa Szewczenki w Kijowie), Dwie pamięci-prawdy w dramacie „,Sen srebrny Salomei” Juliusza Stowackiego. O raptularzach poety jako podręcznym narzędziu pamięci operującej kodem werbalnym i wizualnym mówił na zakończenie pierwszego dnia konferencji prof. dr hab. Zbigniew Przychodniak (Uniwersytet Adama Mickiewicza), Raptularz podróży wschodniej Juliusza Stowackiego - przestrzeń pamięci poetyckiej. Jego referat wywołał ożywioną dyskusję nad miejscem w spuściźnie poety odnalezionego w 2012 roku rękopisu, skłaniając także ponownie, w perspektywie badań nad pamięcią, do rozważań nad relacją między kodem werbalnym i wizualnym w twórczości Słowackiego. Przedmiotem szczególnego zainteresowania zebranych okazała się także problematyka ukraińska - zarówno obecność Ukrainy w dziełach poety, jak i pamięć o poecie na Ukrainie w czasach współczesnych. Doc. dr hab. Maria Bracka i prof. Rościsław Radyszewski w sposób przekonujący przedstawili niegasnące zainteresowanie Słowackiego tym obszarem, jednocześnie wskazując na paradoks, jakim jest niemalże całkowita niepamięć współczesnej Ukrainy o poecie, który poświęcił jej tak wiele uwagi. Dyskusja wokół tych tematów zakończyła się dopiero w chwili zamknięcia gmachu Muzeum, po trwającym nieprzerwanie dziewięć godzin pierwszym dniu obrad.

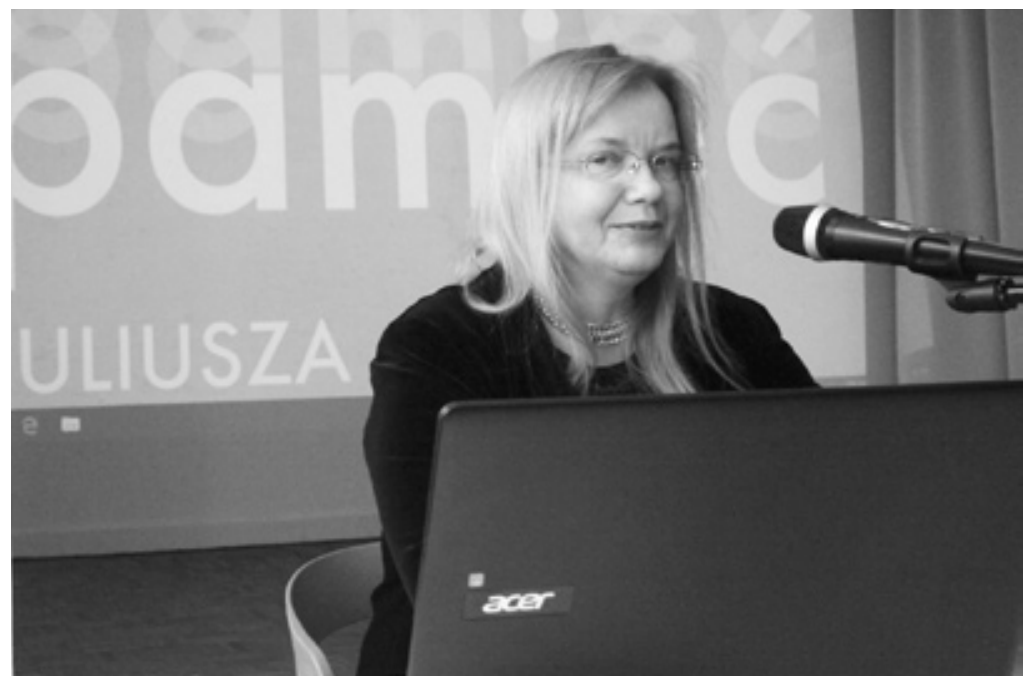

Dr hab. Magdalena Saganiak, prof. UKSW podczas drugiego dnia obrad. Fot. M. Bociański (Muzeum Literatury) 
Drugi dzień konferencji rozpoczął się wystąpieniami poświęconymi pamięci w genezyjskiej twórczości Słowackiego. Prelegenci sięgnęli zarówno do wczesnych tekstów genezyjskich, takich jak Genezis z Ducha, jak i do późniejszych utworów, pokazując rozwój myśli, której celem było wejrzenie w świat ducha. Zjawiska pamięci i zapominania, zdaniem badaczy, należy rozpatrywać w ścisłym związku z wizją i objawieniem, których interpretacja przez pryzmat kategorii pamięci przynosi nowe rozstrzygnięcia $\mathrm{w}$ zakresie rozumienia myśli genezyjskiej. Obrady rozpoczęło wystąpienie dr. hab. Grzegorza Kubskiego, prof. UAM, który wygłosił referat zatytułowany Tożsamość medytujacego oraz „,wspomnienie niby”, ,rewelacja”, ,śnienie niby” w ,,Genezis z Ducha”. Kolejne wystąpienia stanowiły próbę wejrzenia w rzeczywistość genezyjskich utworów w perspektywie nieskończonej pamięci ducha i niemal zupełnej niepamięci wcielenia. Referaty podejmujące ten problem wygłosili: dr hab. Magdalena Saganiak, prof. UKSW, Kosmogonia Stowackiego, czyli pamięć Ducha o absolutnym początku; mgr Natalia Szerszeń (Uniwersytet Warszawski), Pamięć a piękno w „Samuelu Zborowskim"; dr hab. Ewa Szczeglacka-Pawłowska (Uniwersytet Kardynała Stefana Wyszyńskiego), Pamięć a życie pozagrobowe. W świetle twórczości późnej Juliusza Stowackiego; prof. dr hab. Jarosław Ławski (Uniwersytet w Białymstoku), Mitopeiczna pamięć „Króla-Ducha”; dr hab. Olaf Krysowski, prof. UW, Niepamięć Króla-Ducha oraz mgr Klaudia Jeznach (Uniwersytet Humanistyczno-Przyrodniczy im. Jana Długosza w Częstochowie), Pamięć i tożsamość. O poetyckiej figurze tożsamości z Orfeuszem i roli pamięci w później twórczości Stowackiego. Podczas dyskusji kwestią cieszącą się dużym zainteresowaniem była problematyka ,żałoby po sobie samym”, przywołana w referacie dr hab. Ewy Szczeglackiej-Pawłowskiej, której wystąpienie było próbą scharakteryzowania podmiotu dysponującego pamięcią za życia i po śmierci, nad czym refleksję w tej części obrad podjęli także inni wypowiadający się w tym panelu prelegenci. Również wystąpienia prof. Jarosława Ławskiego i dr. hab. Olafa Krysowskiego, prof. UW spotkały się z uznaniem i uwagą jako odkrywające nieznane dotąd wymiary pamięci o czasach minionych i przyszłych w królestwie Ducha. Zaprezentowane w tej części referaty, dzięki konfrontacji dotychczasowego stanu badań nad myślą genezyjską z kategorią pamięci, ukazały w zupełnie nowej perspektywie podstawowe poglądy Słowackiego z ostatniej dekady twórczości. Ujęcie to będzie wymagało nie tylko dodatkowego namysłu, lecz także szeroko zakrojonych badań nad znaczeniem pamięci w okresie genezyjskim. 


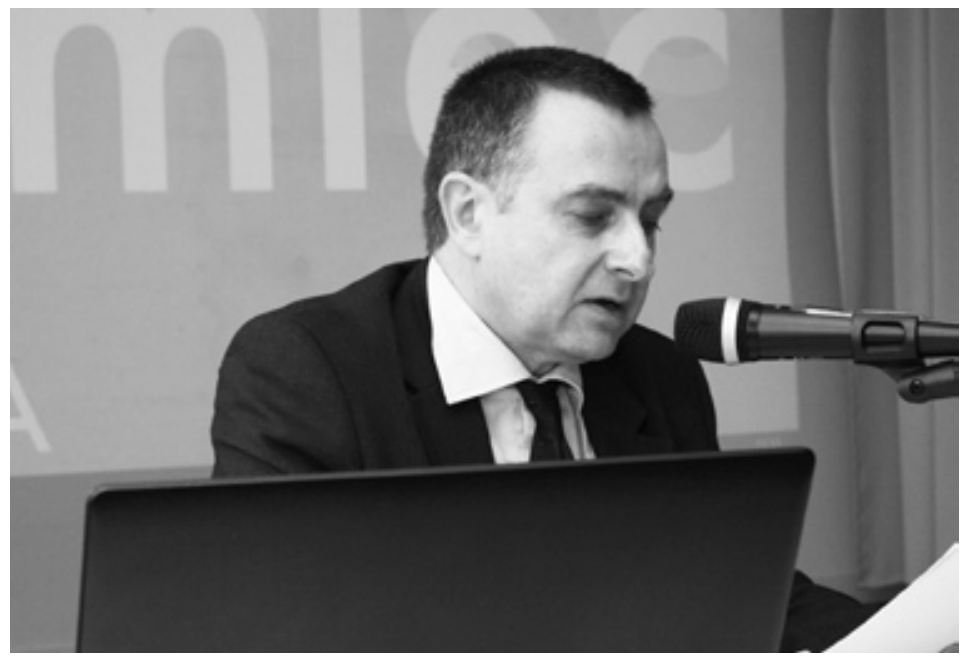

Drugi dzień Konferencji. Referat wygłasza dr hab. Olaf Krysowski, prof. UW. Fot. M. Bociański (Muzeum Literatury)

Kolejna część obrad była poświęcona pamięci Słowackiego o konkretnych osobach. Referaty wygłoszone w tym panelu przypomniały sylwetki postaci znaczących dla poety, między innymi jego matkę Salomeę, przyjaciela Ludwika Spitznagla, ojczyma Augusta Bécu oraz ważnych dla niego duchownych. Zakres oraz treść tych wystąpień były zróżnicowane, o czym świadczą już tytuły referatów: dr Krzysztof Korotkich (Uniwersytet w Białymstoku), Między wspomnieniem a objawieniem. Obraz świata duchowego w ,Listach do matki” Stowackiego; mgr Marta Dziedzicka (Uniwersytet Warszawski), Poświęcić chwile wspomnieniom i szczerej przyjaźni, czyli Juliusza Słowackiego upamiętnienie Ludwika Spitznagla; prof. dr hab. Leszek Libera (Uniwersytet Zielonogórski), Niepamięć - pamięć o ojczymie, doktorze Auguście Bécu; dr hab. Ewa Hoffmann-Piotrowska (Uniwersytet Warszawski), Pamięć Juliusza Słowackiego o sobie samym; dr Marta Białobrzeska (Uniwersytet w Białymstoku), Pamięć o „,Marii” i Antonim Malczewskim w poetyckiej refleksji Juliusza Słowackiego oraz dr hab. Włodzimierz Toruń, prof. KUL, Kapłani w pamięci Juliusza Słowackiego. Ponadto dr hab. Karol Samsel (Uniwersytet Warszawski) wygłosił referat podejmujący problematykę z pogranicza refleksji metodologicznej i badań nad pamięcią, w którym rozważał możliwość porównywania mechanizmów pamięci w utworach Słowackiego i u angielskich poetów jezior: Pastereczka 


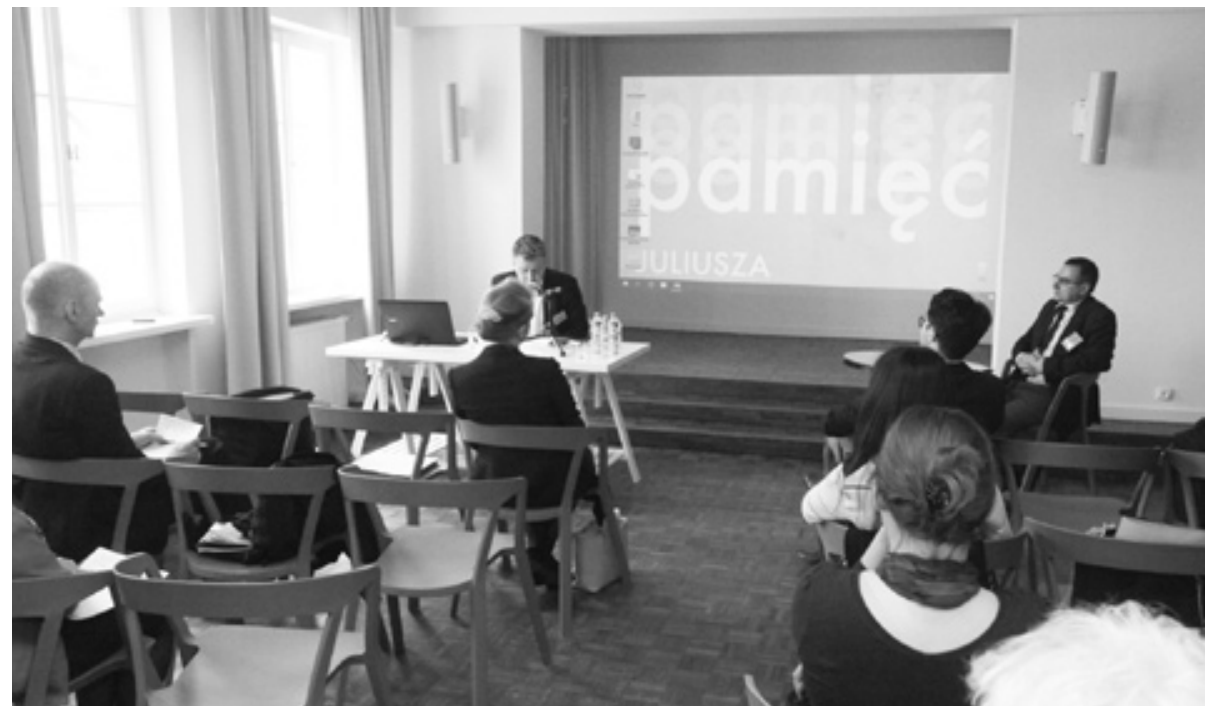

Drugi dzień Konferencji. Referat wygłasza dr hab. Karol Samsel. Fot. M. Bociański (Muzeum Literatury)

i cyganiątko, czyli pod jakimi warunkami jest możliwa komparatystyka tekstów genezyjskich. Dr Maria Makaruk (Uniwersytet Warszawski) w swoim wystąpieniu (Teatralna) pamięć o „Kordianie” przedstawiła namysł nad pamięcią o Juliuszu Słowackim w teatrze.

Tak zróżnicowana tematyka wygłoszonych referatów wywołała pytania i uwagi, które otworzyły nową perspektywę myślenia o relacjach Słowackiego z osobami z jego otoczenia. Temat konferencji wzbudził refleksję nad sposobem, w jaki poeta pamiętał o swoich bliskich i jak zapamiętywał poznawane osoby, a także nad tym, co nie utrwaliło się we wspomnieniach, a być może miało istotne znaczenie dla rozwoju myśli i poglądów poety w kolejnych latach życia.

Choć podczas pierwszych dwu dni konferencji poruszono już tak wiele zagadnień związanych z pamięcią, trzeci dzień upłynął pod znakiem wystąpień eksplorujących jeszcze inne, wcześniej tylko sygnalizowane problemy. Obrady rozpoczęły się wystąpieniem prof. dr. hab. Wacława Pyczka (Katolicki Uniwersytet Lubelski) „,Anhelli” - pamięć i tożsamość, dotyczący tożsamościotwórczej roli chrześcijaństwa dla wspólnoty przedstawionej w powieści. Problem pamięci o wspólnocie politycznej w perspektywie socjalnej i eschatologicznej zaprezen- 


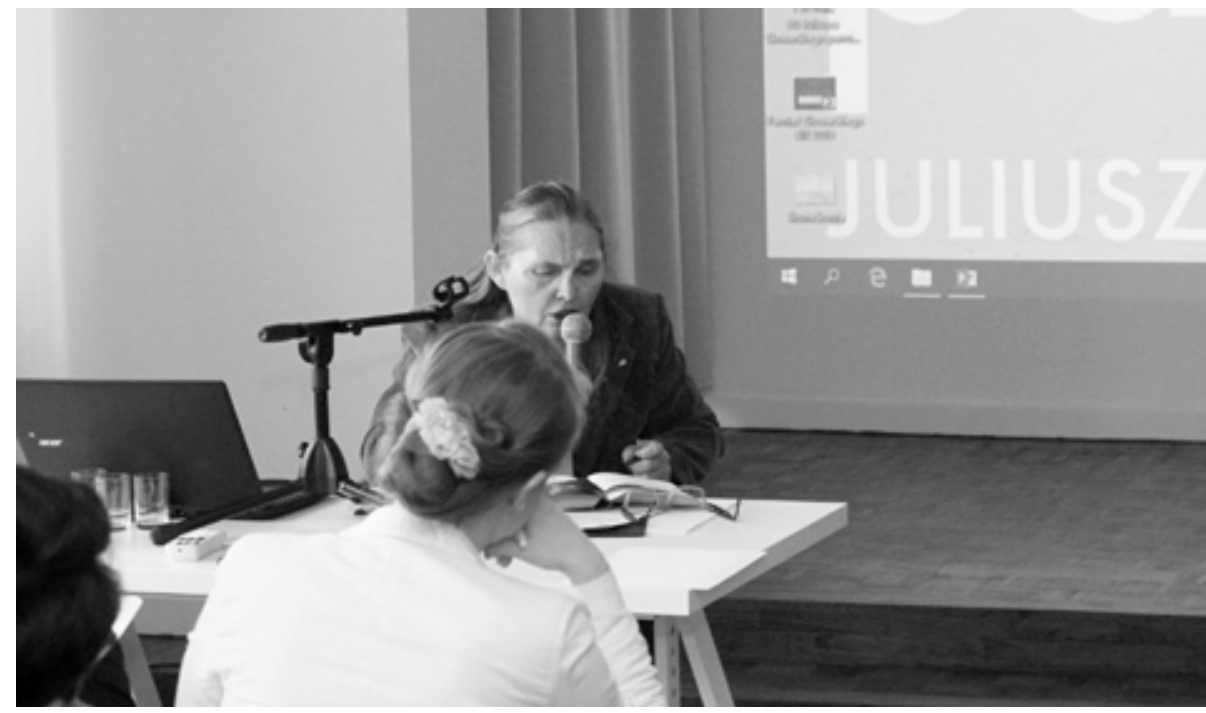

Trzeci dzień obrad. Referat wygłasza prof. dr hab. Kwiryna Ziemba (Uniwersytet Gdański). Fot. M. Bociański (Muzeum Literatury)

tował mgr Jakub Pyda (Uniwersytet Warszawski) w wystąpieniu Wzgląd na ziemię, troska o niebo. Juliusza Słowackiego i Zygmunta Krasińskiego pamięć polityczna. Kwestię niezwykle interesującej relacji pamięci i ciała poruszyły: prof. dr hab. Kwiryna Ziemba (Uniwersytet Gdański), w wystąpieniu Pamięć i ciato jako uobecnienie przeszłości w twórczości Słowackiego, komentując głównie dzieła dramatyczne oraz mgr Anna Rzepniewska (Uniwersytet Warszawski), która w referacie Juliusza Stowackiego pamięć ciała przedstawiła poetę jako nowoczesnego teologa ciała.

W dalszej części panelu prelegenci przybliżyli zebranym problematykę recepcji twórczości i postaci Juliusza Słowackiego - taki charakter miały wystąpienia, które wygłosili dr hab. Maciej Szargot, prof. UŁ, Stowacki czyta Krasińskiego; dr hab. Urszula Kowalczuk (Uniwersytet Warszawski), Pamięć Stowackiego i pamięć o Stowackim jako świadectwo historycznoliterackie w badaniach przełomu XIX i XX wieku; mgr Joanna Dobrowolska (Uniwersytet Warszawski), Pamięć o Stowackim w Młodej Polsce. Studia Cezarego Jellenty nad psychologia twórczości poety; mgr Daria Domarańczyk (Uniwersytet Łódzki), Psychobiografia Juliusza Stowackiego na łamach „Ateneum”. W ramach ostatniego panelu powróciło zagadnienie kultywowania pamięci o poecie w czasach 
współczesnych - doc. dr Irena Fedorowicz (Centrum Polonistyczne Uniwersytetu Wileńskiego) zaprezentowała referat Pamięć o Juliuszu Stowackim na Litwie w XX i XXI wieku. Dr hab. Dorota Kulczycka, prof. UZ przedstawiła analizę filmowej interpretacji Mazepy: Reżyser pyta o Juliusza Stowackiego. „Blanche” Waleriana Borowczyka (1971 r.) jako adaptacja „,Mazepy”; natomiast dr hab. Andrzej Fabianowski, prof. UW w wystąpieniu Pamięć alternatywna. „Jul” Pawła Goźlińskiego poświęcił uwagę powieści, której głównym bohaterem jest Słowacki, a która w sposób budzący kontrowersje odwołuje się do faktów z życia poety. Referat ten wywołał ożywienie wśród uczestników, pytających między innymi o celowość zabiegów polegających na zacieraniu granicy między faktami a fikcją literacką. Duże zainteresowanie słuchaczy wzbudziła również młodopolska recepcja twórczości poety, którą prelegentki nakreśliły, znacznie wykraczając poza najbardziej znane dzieło Ignacego Matuszewskiego Słowacki i nowa sztuka.

Konferencja cieszyła się dużym zainteresowaniem badaczy zarówno z polskich, jak i zagranicznych ośrodków naukowych, co skłoniło organizatorów do wydłużenia obrad, planowanych początkowo na dwa dni, o jeden dodatkowy dzień. Dzięki gościnności i wsparciu Muzeum Literatury im. Adama Mickiewicza obrady obfitowały w dyskusje nie tylko nad problemami pamięci, lecz także nad wymagającymi multimedialnych wizualizacji metodami badania i edycji tekstów Juliusza Słowackiego.

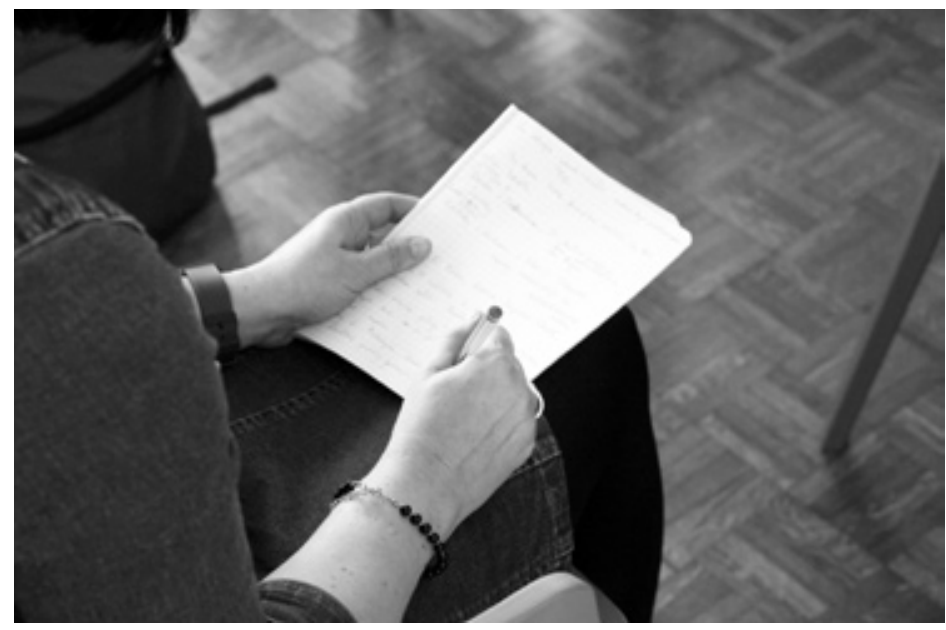

Notatki z Konferencji.

Fot. M. Bociański (Muzeum Literatury) 
Kategoria pamięci okazała się swoistym kluczem otwierającym rozmaite perspektywy badań nad utworami poety. Spojrzenie na twórczość Słowackiego przez pryzmat pamięci okazało się pomysłem poszerzającym wiedzę na temat biografii autora, poetyki jego dzieł, wyobraźni plastycznej i muzycznej, myśli genezyjskiej, refleksji historycznej i historiozoficznej, geografii literackiej oraz recepcji twórczości poety. Konfrontacja dotychczasowego stanu badań z kategorią pamięci stworzyła możliwość pełniejszego zrozumienia konstrukcji i treści dzieł Słowackiego.

Materiały zaprezentowane na konferencji zostaną opublikowane w monografii zbiorowej, która ukaże się nakładem Wydawnictwa Uniwersytetu Warszawskiego. Prace nad książką trwają. 